\title{
PRODUCTION FACTORS INFLUENCING MECHANICAL AND PHYSICAL PROPERTIES OF FDM PRINTED EMBOSSING DIES
}

\author{
Bojan Banjanin (D), Gojko Vladić (D), Magdolna Pál (D), \\ Vladimir Dimovski, Savka Adamović (D), Gordana Delić \\ University of Novi Sad, Faculty of Technical Sciences, \\ Department of Graphic Engineering and Design, Novi Sad, Serbia
}

\begin{abstract}
Embossing technique is an essential operation in the print finishing process. It entails permanently changing the shape of the paper surface by applying pressure with the embossing die, so as to create a recessed or raised image. Embossing dies are made using conventional techniques such as chemical etching or milling. These techniques in the production of conventional embossing die imply the use of different machines and devices, plenty workspace, and often insufficient flexibility in quick job changes. By replacing conventional with additive manufacturing techniques, these problems imposed by the market can be overcome to a great extent.

Using additive manufacturing techniques in embossing dies production process requires prior understanding of factors influencing mechanical and physical properties of produced samples. Fused Deposition Modelling (FDM) technique is commonly used in additive manufacturing due to its simplicity and availability. The surface roughness of FDM produced embossing dies is an important factor which can alter the quality of the embossed paper material. Excellent mechanical properties of the die are also required due to pressure forces applied in the embossing process.

This paper aims to investigate the influencing process factors in FDM additive manufacturing found in current scientific researches and implement these findings for embossing dies production. Influence of these factors on surface roughness, tensile and compression strength, the quantity of used material and production time were investigated.

Findings imply that vast variety of process factors influence chosen dependent variables of samples printed with FDM technique. Many researchers have investigated these factors, but mainly in the field of industrial engineering, electronics and bioengineering. Hence, the importance of this paper is in finding a way to implement these findings in the field of graphic engineering and design.
\end{abstract}

Key words: Fused Deposition Modelling, embossing dies, FDM process factors, mechanical and physical properties

\section{INTRODUCTION}

In the graphic production process, there is a noticeable trend of reducing print runs, and increasing demand of personalized products with the capability of quick makeready times, which requires from manufacturers to finish a whole production process in one place. In personalized production, embossing dies (Figure 1) withstand a lower number of imprints; hence different approach of their production should be considered. Production of these dies needs to be simplified, to cost less and to satisfy all the necessary criteria such as high production precision and good mechanical and physical characteristics.

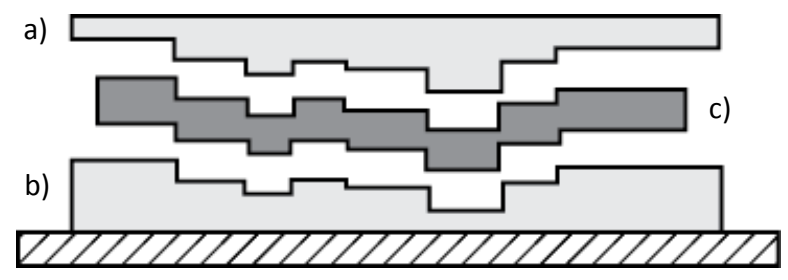

Figure 1: Embossing tool with a) male die and b) female die used for embossing c) paper

Recently, there appear to be more manufacturers of graphic equipment and materials who introduces additive manufacturing in their production process. Additive manufacturing (AM) techniques refer to the 
production of 3D objects by adding material in successive layers. Mainly these techniques were used for the production of prototypes (rapid prototyping - RP), but recently they have been used for commercial, industrial purposes (Masood et al, 2004). Constant improvements in the area of additive manufacturing and wide availability of its techniques enabled their vast utilization in education and domestic production. One of the most represented 3D technique is based on material extrusion (also known as FDM - Fused Deposition Modelling). Synonyms for this technique are also: "plastic jet printing", "thermoplastic extrusion" or "fused filament method" (Bogue, 2013). FDM technique is invented in the year 1988. By Scott Crump, but its commercialisation was done by Stratasys company in the year 1990. (Stratasys, 2016). A solid filament of material is fed into printing head where it is heated and pushed through nozzles onto a building platform where it is deposited in successive layers. Each layer of extruded material is cooled down and solidified once being deposited on the platform (Figure 2).

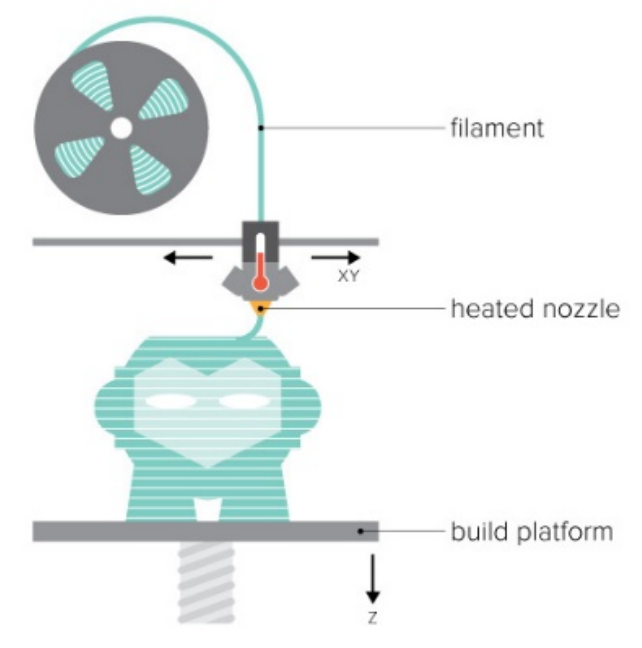

Figure 2: Principle of FDM printing process (3dlink, 2016)

Successive layers form a 3D printed object which has an anisotropic property (Ahn et al, 2002). Common materials used in FDM printing process are acrylonitrile butadiene styrene (ABS), polylactic acid (PLA), nylon, polycarbonate (PC), polyether ether ketone (PEEK), etc. Composite materials gain interest in academic circles due to the variety of improved properties which cannot be achieved only with a plain thermoplastic material. Clay, glass, wood and metal particles are often added to the thermoplastic matrix to improve one of the material properties. Objects produced with FDM technique have good mechanical properties but less surface quality which can be improved using one of the print finishing techniques (Yan et al, 1996; Wendel et al, 2008; Upcraft et al, 2003; Wong et al, 2012). FDM technique is characterized by its simplicity, availability of different printing materials and low price. Use of biodegradable materials such as polylactic acid (PLA) allows printed objects to be biodegradable which leads to a decrease in the negative effect on living and working environment.

Conventional techniques of embossing dies production are chemical etching and machining. Machining is carried out by removing excess material with machining tools in order to get the desired shape of the embossing die. Chemical etching techniques usually use nitric acid to remove certain parts of the embossing die. Both of these techniques produce by-products which can be hazardous to humans and their environment.

\subsection{Parameters influencing embossing process}

There are a lot of influencing parameters that affect the quality of embossed images on graphic products. They can be divided into three categories (Konstantinović, 1997):

- $\quad$ parameters of embossing die

- $\quad$ parameters of embossing substrate

- $\quad$ parameters of working parameters 
Before production of embossing dies it is necessary to know optimal size and shape of embossing elements, the number of details, gap between elements on male and female die part and depth of embossing elements. Element precision, their size and number of impressions dictates the choice of die material. Brass and copper dies are used for high circulations and fine precision of embossing elements. Magnesium dies are softer and are used for lower circulation, pressure and lower quality of fine embossing elements (u-emboss, n.d; Rikard, 2016; Iggesund, 2018). The gap between elements on the male and female die is defined in the process of preparing files for filming. A small gap is used for embossing thinner papers, and larger ones are used for thicker papers often with rough surface structure. A depth of embossing elements is controlled in the process of chemical etching or machining.

Parameters of embossing substrate (usually paper) also affect the quality of the embossing process. Different papers require different die parameters and work parameters. If the elements on the embossing die are small and depth of embossing is large, it is necessary to acquire proper hardness, stiffness, toughness and elasticity of paper to achieve optimum embossing results. Essential paper characteristics are tensile and compressive strength and strain, hardness, stiffness, density and percentage of moisture in paper structure (Kirwan, 2013). If relative humidity in paper rises, plastic deformation will be higher (Konstantinović, 1997).

According to Konstantinović (1997), working parameters are applied pressure, the embossing die temperature and contact time between paper and die during the embossing process. In order to achieve plastic deformation of the embossing material, it is required to overcome its resistance. Plastic deformation is the objective criteria for determining embossing quality. According to Blechschmidt (2013), optimum embossing depth is between $0.3 \mathrm{~mm}$ and $0.6 \mathrm{~mm}$. In embossing process, ultimate deformation is calculated as a sum of elastic, elasto-plastic and plastic deformation of material Eq. (1):

$\varepsilon_{\mathrm{uk}}=\varepsilon_{\mathrm{e}}+\varepsilon_{\mathrm{ep}}+\varepsilon_{\mathrm{p}}$

Where $\varepsilon_{u k}$ is ultimate deformation, $\varepsilon_{e}$ is elastic deformation, $\varepsilon_{e p}$ is elasto-plastic deformation, and $\varepsilon_{p}$ is plastic deformation. Wilken (ed. Holik, 2013) defines the embossing process as forming material by using pressure. Required pressure depends on the embossing area and specific material resistance Eq. (2):

$\mathrm{F}=\mathrm{C} \cdot \sigma_{0} \cdot \mathrm{A}$

where $c$ stand for the correction factor. Elastic deformation of material ends after applying pressure, and the final result of embossing is defined by ultimate plastic deformation implied upon the material. By adjusting the gap between raised and recessed die, it is also possible to control embossing pressure. Blechschmidt (2013) points out that optimum pressure should be between $25 \mathrm{MPa}$ and $35 \mathrm{MPa}$.

The temperature of the embossing die can also be regulated. The optimum combination of pressure and temperature will yield high-quality embossing result. The same results can be achieved by lowering the pressure and rising temperature or by applying greater pressure and lower temperature (Konstantinović, 1997). Contact time is defined as a time of applying pressure of embossing die on a substrate. By increasing contact time, plastic deformation of material increases. Contact time depends on the level of automation and construction of the embossing machine, the surface structure of embossing material, material properties as well as the type of embossing process (Konstantinović, 1997). Optimum contact time should be between 0.3 and 3 seconds (Blechschmidt, 2013).

\subsection{Requirements for embossing dies produced using additive manufacturing}

Embossing dies produced by one of the additive manufacturing techniques need to have good mechanical properties, smooth surface and good reproduction of fine embossing elements. In order to replace conventionally produced embossing dies with ones produced by AM technique, it is necessary to have a good quality of reproduced elements and to ensure the desired number of impressions without die failure. Satisfying embossing requirements using FDM produced dies will probably ensure desired quality by using other AM techniques such as vat photo polymerization, binder jetting, laser sintering etc.

To achieve these requirements, FDM printed dies have to overcome problems of surface quality (usually caused by "staircase effect"), mechanical strength and precise reproduction of fine elements. These output 
variables are commonly researched in scientific circles and will be discussed in this paper. It is also of great importance to produce embossing dies for the least possible time and to ensure that usage of printing material is reduced as much as it is possible while retaining a good quality of dies.

\section{FACTORS INFLUENCING QUALITY OF FDM PRINTED PRODUCTS}

There are a great number of factors influencing the quality of objects produced using FDM 3D printing technique such as printing material properties, the height of deposited layers, type and percentage of infill, number of shells, extruding temperature, printing speed, print orientation, raster angle etc. Embossing dies produced with FDM technique require appropriate mechanical properties, surface roughness, and reproduction of small embossing elements, low price and production time in order to justify their use in the embossing process. Influence of the above-mentioned factors on the properties of FDM printed parts is discussed in the next chapter. First basic terminology must be defined.

Layer height (slice height, layer thickness) - This factor is the most researched in academic circles so far, and it refers to the thickness of the layer deposited by nozzle tip in " $z$ " direction of the printing surface. This factor determines "resolution" of side surfaces of the FDM printed object. The lower the value of layer height is, the finer side surface quality will be achieved. By increasing layer height, the so-called "staircase effect" will be more visible leading to rougher side surfaces (Ahn et al, 2002; Mohamed et al, 2015).

Air gap - This parameter refers to the distance between two deposited filaments (rasters) on the same layer determining the percentage of object infill. Because of its anisotropic structure, FDM printed objects are formed with interlaced rasters trapping a certain amount of air between them. Smaller air gaps lead to the more compact structure of the 3D printed object with stronger inter-filament bonds and better mechanical properties (Ahn et al, 2002; Mohamed et al, 2015).

Raster width (bead width) - This parameter refers to the width of the deposited filament in "xy" direction, and it is commonly controlled by adjusting extruder temperature. Ahn et al. (2002). Wider raster width leads to part with the stronger interior but increased production time (Ahn et al, 2002; Mohamed et al, 2015).

Raster angle (raster orientation) - beside layer height, this is one of the most influencing parameters found in the literature. It refers to the angle between rasters and " $x$ " axis of the print surface. Most commonly used values of this parameter are $0^{\circ}, 45^{\circ}$ and $90^{\circ}$ but angles of $20^{\circ}, 30^{\circ}, 60^{\circ}$ etc. are also investigated in the listed literature (Ahn et al, 2002; Mohamed et al, 2015).

Contour width - this parameter refers to the width of the layer's outer contour also know as a shell which surrounds the part (Mohamed et al, 2015).

Contour to contour air gap - refers to the gap between outer contours if the part is printed with multiple contours (Mohamed et al, 2015).

Perimeter to raster air gap - this parameter refers to the gap between the innermost contour and the edge of the rasters in infill (Mohamed et al, 2015).

Build orientation - this parameter defines an angle between the printed object and build platform along " $x$ ", " $y$ " and "z" axis (Mohamed et al, 2015).

Type of infill - refers to the inner geometry of the printed object. There are many different shapes of inner infill like linear, hexagonal, diamond and some which have more of an aesthetic function (marroccanstar, catfill, sharkfill, etc.) (3dhubs, 2017).

Infill (percentage of infill) - determines gaps in the inner structure of 3D printed object. Variation in values in this parameter printed object will be more or less filled with deposited filament (3dhubs, 2017).

Number of contours (shells) - this parameter refers to the number of deposited filaments that form outer walls of the printed object. By varying values of this parameter, object will be printed with thinner or thicker walls (Mohamed et al, 2015).

Floor/roof thickness - these parameters are not thoroughly investigated in the academic community. They refer to number (commonly described through thickness) of first few layers (floor) or last few layers (roof) 
printed with $100 \%$ linear infill. Adjusting these parameter allows the printed object to have a dense cover (3dhubs, 2017).

Nozzle temperature (model build temperature) - refers to the temperature of the heating element (nozzle) which controls the viscosity of the semi-molten material (Ahn et al, 2002).

Colour of the material - this parameter refers to the addition of different colorants to the base matrix of thermoplastic material used in FDM (Ahn et al, (2002).

Nozzle diameter - refers to the diameter of the printhead nozzle tip. Adjusting this parameter allows different raster widths to be extruded on the build platform (Ahn et al, 2002).

Envelope temperature (environment or build platform temperature) - This parameter refers to the temperature of the surrounding atmosphere during the printing process (Ahn et al, 2002).

In the work of Mohamed et al (2015) a review of the influencing process parameters on the quality of FDM printed objects are listed. It is important to choose which of these parameters are going to be analysed and which should be constrained in order to have a desirable quality of printouts. Classification of influencing factors derived from the works of Mohamed et al (2015) and Ahn et al. (2002) is presented in Table 1.

Table 1: Factors influencing the quality of FDM produced parts (Mohamed, Masood and Bhowmik, 2015; Ahn et al, 2002)

\begin{tabular}{|c|c|c|c|c|c|}
\hline \multicolumn{6}{|c|}{ INFLUENCING FACTORS OF FDM PRINTING TECHNIQUE } \\
\hline $\begin{array}{l}\text { QUALITY OF 3D } \\
\text { MODEL }\end{array}$ & $\begin{array}{l}\text { ORIENTATION ON } \\
\text { BUILD PLATFORM }\end{array}$ & $\begin{array}{l}\text { SETIINGS OF FDM } \\
\text { PRINTER }\end{array}$ & $\begin{array}{l}\text { WORKING } \\
\text { PARAMETERS }\end{array}$ & $\begin{array}{l}\text { UNPROCESSED } \\
\text { MATERIAL }\end{array}$ & $\begin{array}{l}\text { ENVIRONMENTAL } \\
\text { FACTORS }\end{array}$ \\
\hline \multirow[t]{13}{*}{ STL FILE } & ALONG X AXIS & $\begin{array}{l}\text { NOZZLE } \\
\text { TEMPERATURE }\end{array}$ & AIR GAP & DENSITY & TEMPERATURE \\
\hline & ALONG Y AXIS & NOZZLE DIAMETER & RASTER ANGLE & COLOUR & HUMIDITY \\
\hline & ALONG ZAXIS & $\begin{array}{l}\text { BUILD PLATFORM } \\
\text { TEMPERATURE }\end{array}$ & TYPE OF INFILL & & \\
\hline & & PRINTER CALIBRATION & RASTER WIDTH & & \\
\hline & & & LAYER HEIGHT & & \\
\hline & & & PERCENTAGE OF & & \\
\hline & & & INFILL & & \\
\hline & & & OBJECT SHRINKAGE & & \\
\hline & & & ALONG $X, Y$ AND $Z$ & & \\
\hline & & & AXIS & & \\
\hline & & & FLOOR/ROOF & & \\
\hline & & & THICKNESS & & \\
\hline & & & CONTOUR WIDTH & & \\
\hline
\end{tabular}

\section{SELECTION OF THE MOST INFLUENCING FACTORS AND OPTIMIZATION TECHNIQUES}

In FDM process it is essential to choose the proper process parameters in order to improve surface roughness, dimensional accuracy, mechanical properties, build time and at the same time to reduce material consumption during the manufacturing of embossing dies.

For determining which processing factors are most influencing regarding specific output variables, Design of experiment (DOE) and Taguchi method are commonly utilized. DOE was introduced as a concept by Ronald Fisher (Fisher, 1925), but most investigations on this topic were done in academic community (Ranjit, 2001). In his work, Fisher demonstrated the usability of his concept in agriculture. He analysed the optimum amount of water, rain, sunlight, fertilizers and soil condition required to gain better harvest (Fisher, 1926). 
Genichi Taguchi broadened the application of this method by introducing a new approach (Taguchi, 1986). This approach implies dividing a problem into two categories by using the logarithmic function of desired output as a target optimization function (called signal to noise $-\mathrm{S} / \mathrm{N}$ ratio). Problems of optimization are divided into two categories:

- $\quad$ Static problems - more than one input variables directly determine the desired value of the output variable. Three approaches can be used: smaller-the-better (when the smallest value of output variable is desired), larger-the-better (when the highest value of output variable is desired) and nominal-is-better (when the desired value is predetermined, and no other values smaller or bigger than that value is desired)

- Dynamic problems - one input variable directly determine the value of the output value

Taguchi optimization technique is able to provide:

- Maximum return funds

- Most efficient settings of machines

- Efficient use of raw materials and energy

- Optimum distribution of work in order to reduce the required labour and production time

The goal of every production process is to achieve the best product quality, least failure and high productivity which can be achieved utilizing full factorial design. In that case, it is necessary to test the interaction between every input factor and their influence on output value which prolong production process and increase cost. In contrast to the full factorial design, the Taguchi method decreases the number of required experiments by using orthogonal arrays. Choosing the adequate orthogonal array is the most laborious task in the Taguchi method (Bolboaca et al, 2007).

Besides full factorial design and Taguchi method, there are some other techniques used in the optimization process. Thrimurthulu et al (2010) used a real coded generic algorithm (GA) to develop an analytical model to predict the optimum part orientation for surface roughness. Horvath et al (2007) used DOE to study the three different input factors to improve the surface roughness of FDM printed ABS samples. Chung Wang et al (2007) integrated the Taguchi method with the grey relational analysis to improve the surface roughness of FDM printed parts by $62.27 \%$. In the work of Sood et al (2010) central composite design (CCD) and analysis of variance (ANOVA) were used for optimization of mechanical properties of FDM parts by investigating the influence of five different input variables. Percoco et al (2012) also used CCD technique to analyse the influence of two process parameters, and chemical treatment of FDM printed parts on their compressive strength and mechanical behaviour. Rayegani and Onwubolu (2014) utilize group method for data handling (GMDH) and differential evolution (DE) for process parameter prediction and optimization of the FDM process. They investigated four input variables on tensile strength.

Usually, research papers are focused on one objective (output) parameter which needs to be optimized by investigating the influence of one input parameter (main effect) or their interactions. Hamel et al (2018) proposed the use of an approximation-assisted multi-objective optimization technique to quantify the performance of an AM system for specific use. The focus of their research is in design for manufacturing (DfAM) techniques and tools needed in the design process regardless of the AM system being used. Mohamed et al (2016) investigated the influence of six input variables on build time, feedstock material consumption and dynamic flexural modulus using Q-optimal response surface methodology. Analysis of variance (ANOVA) technique was used to test the adequacy and significance of mathematical models. As a result, the optimal setting of process parameters was determined. Authors proved that Q-optimal design type of response surface methodology was simple, efficient, powerful, flexible, cost-effective and reliable design for process optimization involving multiple input and output variables. In Table 2 Input factors and their influence on output variables investigated in the literature are listed. 
Table 2: Input factors and their influence on output variables investigated in the literature

\begin{tabular}{|c|c|c|c|c|c|c|}
\hline Input Output & $\begin{array}{l}\text { Surface roughness } \\
\text { (surface finish) }\end{array}$ & $\begin{array}{c}\text { Dimensional accuracy } \\
\text { and sample } \\
\text { deformation }\end{array}$ & $\begin{array}{c}\text { Static mechanical } \\
\text { properties (tensile } \\
\text { strength, } \\
\text { compression } \\
\text { strength) } \\
\end{array}$ & $\begin{array}{l}\text { Dynamic } \\
\text { mechanical } \\
\text { properties }\end{array}$ & Build time & $\begin{array}{c}\text { Feedstock } \\
\text { material }\end{array}$ \\
\hline Layer height & $\begin{array}{l}\text { Huang et al. (2018); Chung } \\
\text { Wang, Lin and Hu (2007); } \\
\text { Thrimurthulu, Pandey and } \\
\text { Venkata Reddy (2004); } \\
\text { Horvath, Noorani and } \\
\text { Mendelson (2007); } \\
\text { Nancharaiah, Raju and } \\
\text { Raju (2010); } \\
\text { Anitha,Arunachalam and } \\
\text { Radhakrishnan, (2001) }\end{array}$ & $\begin{array}{c}\text { Chung Wang, Lin and Hu } \\
\text { (2007), Sahu, Mahapatra } \\
\text { and Sood (2013); Zhang } \\
\text { and Peng } \\
\text { (2012);Nancharaiah, } \\
\text { Raju and Raju (2010); } \\
\text { Sood, Ohdar and } \\
\text { Mahapatra (2009);Zhang } \\
\text { and Chou (2008); Xinhua } \\
\text { et al. (2015) }\end{array}$ & $\begin{array}{c}\text { Huang et al. (2018); } \\
\text { Sood, Ohdar and } \\
\text { Mahapatra (2010); } \\
\text { Chung Wang, Lin and } \\
\text { Hu (2007); } \\
\text { Chin Ang et al. (2006); } \\
\text { Hamel, Salsbury and } \\
\text { Bouck (2018) }\end{array}$ & $\begin{array}{c}\text { Mohamed, } \\
\text { Masood and } \\
\text { Bhowmik (2016); }\end{array}$ & $\begin{array}{c}\text { Mohamed et al. } \\
\text { (2016); Hamel, } \\
\text { Salsbury and Bouck } \\
\text { (2018); Kumar and } \\
\text { Regalla (2012); } \\
\text { Nancharaiah (2011); } \\
\text { Thrimurthulu, Pandey } \\
\text { and Venkata Reddy } \\
\text { (2004) }\end{array}$ & $\begin{array}{l}\text { Mohamed, } \\
\text { Masood and } \\
\text { Bhowmik } \\
\text { (2016); }\end{array}$ \\
\hline Raster width & $\begin{array}{l}\text { Nancharaiah, Raju and } \\
\text { Raju (2010); Anitha, } \\
\text { Arunachalam and } \\
\text { Radhakrishnan, (2001) }\end{array}$ & $\begin{array}{c}\text { Sahu, Mahapatra and } \\
\text { Sood (2013); Zhang and } \\
\text { Peng (2012); } \\
\text { Nancharaiah, Raju and } \\
\text { Raju (2010); Sood, } \\
\text { Ohdar and Mahapatra } \\
\text { (2009); Zhang and Chou } \\
\text { (2008); Xinhua et al. } \\
\text { (2015) }\end{array}$ & $\begin{array}{c}\text { Masood, Mau and } \\
\text { Song (2010); Rayegani } \\
\text { and Onwubolu (2014); } \\
\text { Percoco, Lavecchia } \\
\text { and Galantucci } \\
\text { (2012); Sood, Ohdar } \\
\text { and Mahapatra } \\
\text { (2010); Chin Ang et al. } \\
\text { (2006); Ahn et al. } \\
\text { (2002); Montero et al. } \\
\text { (2001); }\end{array}$ & $\begin{array}{l}\text { Mohamed, } \\
\text { Masood and } \\
\text { Bhowmik } \\
\text { (2016);Arivazhag } \\
\text { an, Masood and } \\
\text { Sbarski (2011) }\end{array}$ & $\begin{array}{l}\text { Mohamed et al. } \\
\text { (2016); Kumar and } \\
\text { Regalla (2012) }\end{array}$ & $\begin{array}{c}\text { Mohamed, } \\
\text { Masood and } \\
\text { Bhowmik } \\
\text { (2016) }\end{array}$ \\
\hline Build orientation & $\begin{array}{l}\text { Huang et al. (2018); } \\
\text { Chung Wang, Lin and Hu } \\
\text { (2007); } \\
\text { Thrimurthulu, Pandey and } \\
\text { Venkata Reddy (2004) }\end{array}$ & $\begin{array}{c}\text { Chung Wang, Lin and Hu } \\
\text { (2007); Sahu, Mahapatra } \\
\text { and Sood (2013); Sood, } \\
\text { Ohdar and Mahapatra } \\
\text { (2009) }\end{array}$ & \begin{tabular}{|} 
Huang et al. (2018); \\
Rayegani and \\
Onwubolu (2014); \\
Sood, Ohdar and \\
Mahapatra (2010); \\
Chung Wang, Lin and \\
Hu (2007); \\
Chin Ang et al. (2006); \\
Ahn et al. (2002); \\
Jami, Masood and \\
Song (2013) \\
\end{tabular} & $\begin{array}{c}\text { Mohamed, } \\
\text { Masood and } \\
\text { Bhowmik (2016); } \\
\text { Jami, Masood } \\
\text { and Song (2013) }\end{array}$ & $\begin{array}{l}\text { Mohamed et al. } \\
\text { (2016); Kumar and } \\
\text { Regalla (2012); } \\
\text { Thrimurthulu, Pandey } \\
\text { and Venkata Reddy } \\
\text { (2004) }\end{array}$ & $\begin{array}{l}\text { Mohamed, } \\
\text { Masood and } \\
\text { Bhowmik } \\
\text { (2016) }\end{array}$ \\
\hline Raster angle & $\begin{array}{c}\text { Huang et al. (2018); } \\
\text { Nancharaiah, Raju and } \\
\text { Raju (2010) }\end{array}$ & $\begin{array}{l}\text { Sahu, Mahapatra and } \\
\text { Sood (2013); } \\
\text { Nancharaiah, Raju and } \\
\text { Raju (2010); } \\
\text { Sood, Ohdar and } \\
\text { Mahapatra (2009) }\end{array}$ & \begin{tabular}{|} 
Huang et al. (2018); \\
Masood, Mau and \\
Song (2010); Rayegani \\
and Onwubolu (2014); \\
Percoco, Lavecchia \\
and Galantucci \\
(2012); Sood, Ohdar \\
and Mahapatra \\
(2010); Montero et al. \\
(2001) \\
\end{tabular} & $\begin{array}{c}\text { Mohamed, } \\
\text { Masood and } \\
\text { Bhowmik } \\
\text { (2016);Arivazhag } \\
\text { an, Masood and } \\
\text { Sbarski (2011) }\end{array}$ & $\begin{array}{l}\text { Mohamed et al. } \\
\text { (2016); Kumar and } \\
\text { Regalla (2012); } \\
\text { Nancharaiah (2011) }\end{array}$ & $\begin{array}{c}\text { Mohamed, } \\
\text { Masood and } \\
\text { Bhowmik } \\
(2016)\end{array}$ \\
\hline Air gap & $\begin{array}{c}\text { Nancharaiah, Raju and } \\
\text { Raju (2010) }\end{array}$ & $\begin{array}{l}\text { Sahu, Mahapatra and } \\
\text { Sood (2013); } \\
\text { Nancharaiah, Raju and } \\
\text { Raju (2010); } \\
\text { Sood, Ohdar and } \\
\text { Mahapatra (2009) }\end{array}$ & \begin{tabular}{|c|} 
Rayegani and \\
Onwubolu (2014); \\
Sood, Ohdar and \\
Mahapatra (2010); \\
Chin Ang et al. (2006); \\
Ahn et al. (2002); \\
Montero et al. (2001) \\
\end{tabular} & $\begin{array}{c}\text { Mohamed, } \\
\text { Masood and } \\
\text { Bhowmik (2016); }\end{array}$ & $\begin{array}{c}\text { Mohamed et al. } \\
\text { (2016); } \\
\text { Nancharaiah (2011) }\end{array}$ & $\begin{array}{c}\text { Mohamed, } \\
\text { Masood and } \\
\text { Bhowmik } \\
\text { (2016) }\end{array}$ \\
\hline Type of infill & $\begin{array}{l}\text { Chung Wang, Lin and Hu } \\
\text { (2007); } \\
\text { Horvath, Noorani and } \\
\text { Mendelson (2007) }\end{array}$ & $\begin{array}{c}\text { Chung Wang, Lin and Hu } \\
\text { (2007); Xinhua et al. } \\
\text { (2015) }\end{array}$ & \begin{tabular}{|c|} 
Masood, Mau and \\
Song (2010); Chung \\
Wang, Lin and Hu \\
(2007); Chin Ang et al. \\
(2006); Hamel, \\
Salsbury and Bouck \\
(2018) \\
\end{tabular} & $\begin{array}{l}\text { Arivazhagan and } \\
\text { Masood (2012); } \\
\text { Arivazhagan, } \\
\text { Masood and } \\
\text { Sbarski (2011) }\end{array}$ & $\begin{array}{l}\text { Hamel, Salsbury and } \\
\text { Bouck (2018) }\end{array}$ & \\
\hline Printing speed & $\begin{array}{c}\text { Huang et al. (2018); } \\
\text { Anitha,Arunachalam and } \\
\text { Radhakrishnan, (2001) }\end{array}$ & $\begin{array}{l}\text { Zhang and Peng (2012); } \\
\text { Zhang and Chou (2008); } \\
\text { Xinhua et al. (2015) }\end{array}$ & Huang et al. (2018) & & & \\
\hline Nozzle temperature & $\begin{array}{l}\text { Horvath, Noorani and } \\
\text { Mendelson (2007) }\end{array}$ & Xinhua et al. (2015) & \begin{tabular}{|c|} 
Ahn et al. (2002; \\
Montero et al. (2001) \\
\end{tabular} & $\begin{array}{c}\text { Arivazhagan and } \\
\text { Masood (2012) } \\
\end{array}$ & & \\
\hline $\begin{array}{l}\text { Number of } \\
\text { contours }\end{array}$ & & & $\begin{array}{l}\text { Hamel, Salsbury and } \\
\text { Bouck (2018) }\end{array}$ & $\begin{array}{c}\text { Mohamed, } \\
\text { Masood and } \\
\text { Bhowmik (2016); }\end{array}$ & $\begin{array}{c}\text { Mohamed, Masood } \\
\text { and Bhowmik (2016); } \\
\text { Hamel, Salsbury and } \\
\text { Bouck (2018) }\end{array}$ & $\begin{array}{c}\text { Mohamed, } \\
\text { Masood and } \\
\text { Bhowmik } \\
(2016) \\
\end{array}$ \\
\hline Support style & $\begin{array}{l}\text { Chung Wang, Lin and Hu } \\
\text { (2007) }\end{array}$ & $\begin{array}{l}\text { Chung Wang, Lin and Hu } \\
\text { (2007) }\end{array}$ & $\begin{array}{c}\text { Chung Wang, Lin and } \\
\text { Hu (2007) }\end{array}$ & & & \\
\hline Colour & & & $\begin{array}{c}\text { Ahn et al. (2002); } \\
\text { Montero et al. (2001) }\end{array}$ & & & \\
\hline Contour width & & & & & $\begin{array}{c}\text { Kumar and Regalla } \\
(2012)\end{array}$ & \\
\hline
\end{tabular}


In Figure 3 presence of most investigated input factors in literature listed in Table 2 are presented.

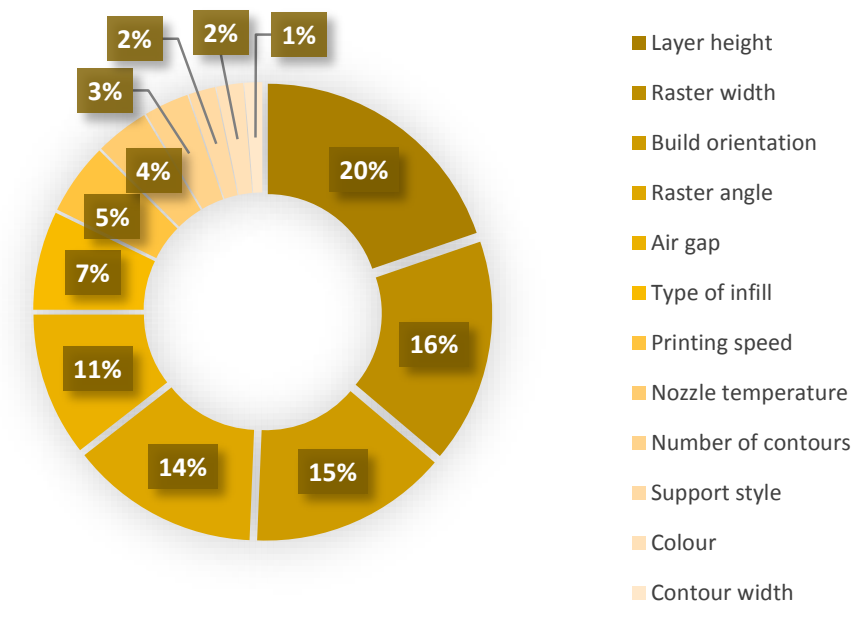

Figure 3: Most investigated input factors found in literature listed in Table 2

From Table 2 and Figure 3 it can be seen that layer height is one of the most investigated input factors in the presented literature followed by raster width, build orientation and raster angle. Their influence on mechanical properties of FDM printed samples and the accuracy of their dimensions are thoroughly investigated.

Factors that influence output variables such as surface roughness, dimensional accuracy, tensile and compression strength, build time and feedstock consumption found in literature and that are chosen as important for the production of FDM printed embossing dies are presented in Table 3.

Table 3: Output variables important for quality of FDM produced embossing dies and their most influencing input variables found in the literature

\begin{tabular}{|l|l|}
\hline \multicolumn{1}{|c|}{ Output variable } & \multicolumn{1}{c|}{ Input variable } \\
\hline Surface roughness \\
(surface finish)
\end{tabular}$\quad \begin{aligned} & \text { - Layer height (Anitha, Arunachalam and Radhakrishnan, 2001) } \\
& \text { - Layer height (Horvath, Noorani and Mendelson, 2007) } \\
& \text { - Layer height (Nancharaiah, Raju and Raju, 2010) } \\
& \text { - Layer height (Huang et al. 2018) }\end{aligned}$


Table 3 shows a selection of factors which are identified as important for the production of FDM embossing dies. It can be seen that layer height is most influencing factor regarding surface finish and build time. Build orientation and raster width are detected as most influencing on dimensional accuracy. Air gap and build orientation are found to be important factors regarding tensile strength. Compression strength is mostly affected by an air gap and raster width according to the listed literature.

\section{CONCUSIONS}

Proper selection of influencing process parameters on the production of embossing dies printed using FDM technique is essential task due to the abundance of various parameters and their setting. Each of these parameters affects the quality of produced die in a certain degree. Knowing which parameters influence desired output variables and adjusting their values to get the optimum quality of embossing die is crucial in implementing additive manufacturing in graphic industry. A lot of work is done on investigating influencing factors of FDM 3D printing technique on quality of produced parts, so there are many resources which can aid in decision making in the production process of embossing dies. Most researches are done regarding the influence of process parameters on mechanical properties, dimensional accuracy and surface finish of FDM printed samples. Input parameters such as layer height, raster width and build orientation are also widely investigated in inspected literature, and general guidelines for adjusting these parameters are provided in respect to the desired outcome. Factors such as a number of contours, nozzle temperature, printing speed and type of infill are less represented and investigated in the research community, so there is still space for further research. Output variables such as feedstock consumption and build time are essential in the process of replacing the conventional production of embossing dies with additive manufacturing techniques and deserves more investigation.

It is evident that layer height is one of the most influencing factors regarding the quality of surface finish. Build orientation is identified as the most important factor for getting the precise dimension of FDM printed samples. For acquiring best tensile strength, build orientation and air gap plays an important role. Build orientation defines the orientation of rasters, and the way object is printed on build platform which affects anisotropy of FDM printed objects altering its mechanical properties. Air gap contributes to the porosity of printed object. Larger air gaps between deposited layers and rasters will lead to the looser inner structure of printed sample decreasing its mechanical properties. Build time appears to be most affected by layer height. Thicker the height of layer is, faster the sample will be printed. The increase of layer height, on the other hand, leads to the rougher surface of the printed sample. Specific recommended values of these parameters are purposely left out because they vary between different printers, feedstock material, dimensions and purpose of desired object etc.

By being aware of the complexity of the FDM process, one can take into consideration all constituting factors for specific use and find their optimum values for getting desired output variables. Applying information presented in this paper can lead to better understanding and solving issues which can appear during the production of FDM printed embossing dies.

\section{ACKNOWLEDGMENTS}

The research is supported by the Ministry of Education, Science and Technology Development of the Republic of Serbia, project number: 35027 "Development of software model for scientific and production improvement in graphic industry"

\section{REFERENCES}

[1] 3D Hubs: "What is 3D Printing? The definitive guide to additive manufacturing", 2018, URL: https://www.3dhubs.com/what-is-3d-printing\#owledge-base (last request 2018-07-17).

[2] 3dlink: "Fdm-technologie 3d printer", 2016, URL: https://www.3dlink.nl/2016/08/23/dddropprinter-in-zeeland/fdm-technology/ (last request 2018-07-20). 
[3] Ahn, S., Montero, M., Odell, D., Roundy, S., Wright, P.: "Anisotropic material properties of fused deposition modeling ABS", Rapid Prototyping Journal, 8 (4), 248-257, 2002. doi: 10.1108/13552540210441166

[4] Anitha, R., Arunachalam, S., Radhakrishnan, P.: "Critical parameters influencing the quality of prototypes in fused deposition modelling", Journal of Materials Processing Technology, 118 (1-3), 385-388, 2001. doi: 10.1016/S0924-0136(01)00980-3

[5] Arivazhagan, A., Masood, S., Sbarski, I.: "Dynamic mechanical analysis of FDM rapid prototyping processed polycarbonate material", Proceedings of the 69th annual technical conference of the society of plastics engineers 2011, (SPE, Boston - Massachusetts, 2011), pages 950-955.

[6] Arivazhagan, A., Masood, S. H.: "Dynamic mechanical properties of ABS material processed by fused deposition modelling", International Journal of Engineering Research and Applications, 2 (3), 2009-2014, 2012.

[7] Blechschmidt, J.: "Papierverarbeitungstechnik", (Hanser Verlag, München, 2013)

[8] Bogue, R.: "3D printing: the dawn of a new era in manufacturing?", Assembly Automation, 33 (4), 307-311, 2013. doi: 10.1108/AA-06-2013-055

[9] Bolboacă, S., Jäntschi, L.: "Design of Experiments: Useful Orthogonal Arrays for Number of Experiments from 4 to 16", Entropy, 9 (4), 198-232, 2007. doi: 10.3390/e9040198

[10] Chin Ang, K., Fai Leong, K., Kai Chua, C., Chandrasekaran, M.: "Investigation of the mechanical properties and porosity relationships in fused deposition modelling-fabricated porous structures", Rapid Prototyping Journal, 12 (2), 100-105, 2006. doi: 10.1108/13552540610652447

[11] Chung Wang, C., Lin, T. W., Hu, S. S.: "Optimizing the rapid prototyping process by integrating the Taguchi method with the Gray relational analysis", Rapid prototyping journal, 13 (5), 304-315, 2007. doi: 10.1108/13552540710824814

[12] Fisher, R.A.: "Statistical Methods for researcher Workers", (Oliver and Boyd, London, 1925.)

[13] Fisher, R.A.: "The arrangement of field experiments", Journal of the Ministry Agriculture of Great Britain, 33, 503-513, 1926.

[14] Hamel, J. M., Salsbury, C., Bouck, A.: "Characterizing the effects of additive manufacturing process settings on part performance using approximation-assisted multi-objective optimization", Progress in Additive Manufacturing, 3 (3), 123-143, 2018. doi: 10.1007/s40964-018-0043-5

[15] Holik, H.: "Handbook of paper and board", Revised and Enlarged Edition, (Wiley-VCH Verlag, Weinheim, 2013.)

[16] Horvath, D., Noorani, R., Mendelson, M.: “Improvement of Surface Roughness on ABS 400 Polymer Using Design of Experiments (DOE)", Materials Science Forum, 561-565, 2389-2392, 2007. doi: 10.4028/www.scientific.net/MSF.561-565.2389

[17] Huang, B., Meng, S., He, H., Jia, Y., Xu, Y., Huang, H.: "Study of processing parameters in fused deposition modeling based on mechanical properties of acrylonitrile-butadiene-styrene filament", Polymer Engineering \& Science, 1-9, 2018. doi: 10.1002/pen.24875

[18] Iggesund: "Embossing and debossing", URL: https://www.iggesund.com/en/knowledge/knowledgepublications/graphics-handbook/finishing/hot-foil-stamping12/ (last request 2018-02-02).

[19] Jami, H., Masood, S. H., Song, W. Q.: "Dynamic response of FDM made ABS parts in different part orientations", Advanced Materials Research, 748, 291-294, 2013. doi: 10.4028/www.scientific.net/AMR.748.291

[20] Konstantinović, V.: "Tehnologija grafičke dorade I i II", (Zavod za udžbenike i nastavna sredstva, Beograd, 1997.)

[21] Kumar, G. P., Regalla, S. P.: "Optimization of support material and build time in fused deposition modeling (FDM)",Applied Mechanics and Materials, 110-116, 2245-2251. 2011. doi: 10.4028/www.scientific.net/AMM.110-116.2245

[22] Masood, S.H., Song, W.Q.: "Development of new metal/polymer materials for rapid tooling using fused deposition modelling", Materials \& Design, 25 (7), 587-594, 2004. doi: 10.1016/j.matdes.2004.02.009

[23] Masood, S. H., Mau, K., Song, W. Q.: "Tensile properties of processed FDM polycarbonate material", Materials Science Forum, 654-656, 2556-2559, 2010. doi: 10.4028/www.scientific.net/MSF.654656.2556 
[24] Mohamed, O., Masood, S., Bhowmik, J.: "Optimization of fused deposition modeling process parameters: a review of current research and future prospects", Advances in Manufacturing, $3(1), 42-53,2015$

[25] Mohamed, O. A., Masood, S. H., Bhowmik, J. L.: "Mathematical modeling and FDM process parameters optimization using response surface methodology based on Q-optimal design", Applied Mathematical Modelling, 40 (23-24), 10052-10073, 2016. doi: 10.1016/j.apm.2016.06.055

[26] Montero, M., Roundy, S., Odell, D., Ahn, S.H., Wright, P.K.: "Material characterization of fused deposition modeling (FDM) ABS by designed experiments", Society of Manufacturing Engineers, 10, 1-21, 2001

[27] Nancharaiah, T., Raju, D. R., Raju, V. R.: “An experimental investigation on surface quality and dimensional accuracy of FDM components", International Journal on Emerging Technologies, 1 (2), 106-111, 2010

[28] Nancharaiah, T.: "Optimization of process parameters in FDM process using design of experiments", International Journal of Emerging Technology, 2 (1), 100-102, 2011.

[29] Percoco, G., Lavecchia, F., Galantucci, L. M.: "Compressive properties of FDM rapid prototypes treated with a low cost chemical finishing", Research Journal of Applied Sciences, Engineering and Technology, 4 (19), 3838-3842, 2012.

[30] Ranjit, K.R.: "Design of Experiments Using the Taguchi Approach: 16 Steps to Product and Process Improvement", (John Wiley, New York, 2001.)

[31] Rayegani, F., Onwubolu, G.: "Fused deposition modelling (FDM) process parameter prediction and optimization using group method for data handling (GMDH) and differential evolution (DE)", The International Journal of Advanced Manufacturing Technology, 73 (1-4), 509-519, 2014. doi: 10.1007/s00170-014-5835-2

[32] Rikard: "The Graphic Designer's Guide to Embossing - ZevenDesign", 2016, URL: https://zevendesign.com/graphic-designers-guide-embossing/ (last request 2018-03-15)

[33] Sahu, R., Mahapatra, S. and Sood, A.: "A Study on Dimensional Accuracy of Fused Deposition Modeling (FDM) Processed Parts using Fuzzy Logic", Journal for Manufacturing Science \& Production, 13 (3), 183-197, 2013. doi: 10.1515/jmsp-2013-0010

[34] Sood, A., Ohdar, R., Mahapatra, S.: "Improving dimensional accuracy of Fused Deposition Modelling processed part using grey Taguchi method", Materials \& Design, 30 (10), 4243-4252, 2009. doi: 10.1016/j.matdes.2009.04.030

[35] Sood, A., Ohdar, R., Mahapatra, S.: "Parametric appraisal of mechanical property of fused deposition modelling processed parts", Materials \& Design, 31 (1), 287-295, 2010. doi: 10.1016/j.matdes.2009.06.016

[36] Stratasys Ltd: “3D Printing \& Additive Manufacturing | Stratasys", 2016, URL: http://www.stratasys.com (last request 2017-12-07)

[37] Taguchi, G.: "Introduction to Quality Engineering: Designing Quality into Products and Processes", (Asian Productivity Organization, New York, 1986.)

[38] Thrimurthulu, K., Pandey, P. Venkata Reddy, N.: "Optimum part deposition orientation in fused deposition modelling", International Journal of Machine Tools and Manufacture, 44 (6), 585-594, 2004. doi: 10.1016/j.ijmachtools.2003.12.004

[39] U-emboss: "Detailed Information on Materials | U-Emboss.com", n.d. URL: http://uemboss.com/information/materials-for-die-making/detailed-information-on-materials/ (last request 2017-12-24).

[40] Upcraft, S., Fletcher, R.: "The rapid prototyping technologies" Assembly Automation. 23 (4), 318330, 2003. doi: 10.1108/01445150310698634

[41] Wendel, B., Rietzel, D., Kühnlein, F., Feulner, R., Hülder, G., Schmachtenberg, E.: “Additive processing of polymers", Macromolecular materials and engineering, 293 (10), 799-809, 2008. doi: 10.1002/mame.200800121

[42] Wong, K. V., Hernandez, A.: "A review of additive manufacturing" ISRN Mechanical Engineering, 1-10, 2012. doi: 10.5402/2012/208760

[43] Xinhua, L., Shengpeng, L., Zhou, L., Xianhua, Z., Xiaohu, C., Zhongbin, W.: “An investigation on distortion of PLA thin-plate part in the FDM process", The International Journal of Advanced Manufacturing Technology, 79 (5-8), 1117-1126, 2015. doi: 10.1007/s00170-015-6893-9

[44] Yan, X., Gu, P.: "A review of rapid prototyping technologies and systems", Computer-Aided Design, 28 (4), 307-318, 1996. doi: 10.1016/0010-4485(95)00035-6 
[45] Zhang, Y., Chou, K.: "A parametric study of part distortions in fused deposition modelling using three-dimensional finite element analysis", Proceedings of the Institution of Mechanical Engineers, Part B: Journal of Engineering Manufacture, 222 (8), 959-968, 2008. doi: 10.1243/09544054JEM990

[46] Zhang, J., Peng, A.: "Process-Parameter Optimization for Fused Deposition Modeling Based on Taguchi Method", Advanced Materials Research, 538-541, 444-447, 2012. doi:

10.4028/www.scientific.net/AMR.538-541.444

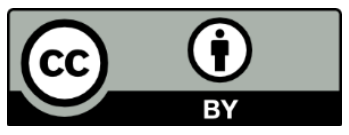

(C) 2018 Authors. Published by the University of Novi Sad, Faculty of Technical Sciences, Department of Graphic Engineering and Design. This article is an open access article distributed under the terms and conditions of the Creative Commons Attribution license 3.0 Serbia (http://creativecommons.org/licenses/by/3.0/rs/). 